\title{
Pemilihan Jalur Terpendek Dalam Pengiriman Bahan Bangunan Menggunakan Metode Djikstra
}

\author{
Imaduddin Agil Firdaus $^{1}$, dan Indra Gita Anugrah ${ }^{2}$ \\ Teknik Informatika Universitas Muhammadiyah Gresik \\ J1. Sumatera No.101 Gresik Kota Baru (GKB),61121 \\ E-mail:agilnazril@gmail.com
}

\begin{abstract}
Abstrak - Optimalisasi pengiriman merupakan sebuah permasalah yang sering terjadi pada setiap perusahaan. Pada studi kasus yang di alami oleh PT. Putra Sejati Bahagia saat ini masih kurang optimal dari segi waktu dan biaya dalam satu kali perjalanan pengiriman bahan bangunan, sehingga pencarian rute tercepat untuk pengiriman bahan bangunan perlu dioptimalkan dari segi waktu dan biaya untuk menentukan lokasi toko-toko mana saja yang dapat dikirim bahan bangunan secara bersamaan. Permasalahan tersebut bisa diselesaikan dengan metode djikstra yang berbasis titik dan node terpilih dan yang belum terpilih, sehingga dapat membantu perusahaan dalam menentukan pilihan toko yang bisa dikirim bahan bangunan. Pada penggunaan system aplikasi algoritma djikstra dapat membantu untuk menentukan rute terpendek yang dapat memilih lokasi terpilih dengan lokasi lain yang belum terpilih, dan juga bisa mengetahui rute mana yang dapat memberikan keuntungan lebih serta dapat memotong perhitungan waktu pengiriman. Karena proses pengiriman dengan menentukan jalur-jalur yang tepat akan memberikan keuntungan lebih dari segi ketepatan waktu dan tidak boros ketika dalam perjalanan. Dalam penelitian ini masih terdapat banyak kekurangan seperti belum dimasukannya parameter cost atau biaya yang dikeluarkan, jenis bahan bangunan permintaan toko sehingga kedepannya penelitian ini masih bisa dikembangkan lebih lanjut lagi.
\end{abstract}

\section{Kata kunci: Supply Chain Management, Djikstra, Pengiriman Barang Bangunan.}

\section{Pendahuluan}

PT. Putra Sejati Bahagiamenjual berbagai jenis bahan bangunan seperti pasir, batu bata, cat, besi, semen dan kebutuhan bahan bangunan lainnya. Pengiriman barang bertujuan untuk menyampaikan barang pada suata tempat yang akan dituju dengan cepat dan dalam kondisi yang masih baik. Keefektifitasan dan keefisienan dalam pengiriman barang dapat mengurangi waktu dan biaya yang dihabiskan untuk melakukan pengiriman barang[10]. Pengiriman barang dapat berjalan efisen, apabila memperhatikan faktor-faktor penting dalam pengiriman barang yaitu faktor wilayah dan muatan. Faktor wilayah dan muatan diperlukan agar pengiriman barang menjangkau wilayah secara menyeluruh serta daya angkut kendaraan mencapai titik optimal[11].

Permasalahaan yang dialami oleh PT. Putra Sejati Bahagia yakni dengan banyaknya permintaan akan bahan bangunan serta tidak dapat mengetahui lokasi proyek yang telah dipesankan bahan bangunannya, sehingga sering terjadi pengiriman bahan bangunan terlambat datang, serta menghabiskan biaya yang besar karena dalamsatu pengiriman bahan bangunan hanya untuk satu proyek saja.

Penelitian yang akan dilakukan adalah untuk mengetahui jalur terpendek dari beberapa proyek yang telah melakukan pembelian bahan bangunan ke PT. Putra Sejati Bahagia. Penentuan jalur terpendek dapat dilakukan dengan memanfaatkan algoritma djikstra.
Djikstra merupakan salah satu bentuk algoritma yang dapat memecahkan suatu permasalahan dalam pencarian lintasan terpendek yang mempunyai panjang minimum dari vertex a-z dalam graph berbobot, dan harus memiliki nilai node yang positif[1]. Sehingga nilai node yang negatif tidak dapat dilalui pada pencarian suatu lintasan algoritma djikstra. Namun apabila nilai node positif lebih pendek tidak dapat ditemukan pada algoritma djikstra, penyelesaian yang dilakukan adalah dengan infiniti (tak hingga). Karena algoritma djikstra merupakan suatu graph berarah yang memiliki nilai node positif, sehingga dapat menentukan nilai suatu lintasan terpendek.

\section{Tinjauan Pustaka}

2.1 Metode Djikstra

Metode Algoritma Djikstra merupakan varian dari salah satu bentuk algoritma greedy[2]. Algoritma djikstra termasuk suatu graph sebuah pohon lintasan yang mempunyai nilai node tersendiri. Dan algoritma djikstra mempunyai nilai positif untuk dapat menyelesaikan sebuah lintasan terpendek dengan sebuah graph yang tidak memiliki nilai cost negative[3]. Sehingga algoritma djikstra selalu di gunakan untuk merouting yang mempunyai nilai cost positif. Algoritma dijkstra menggunakan adjacentlist untuk merepresentasikan sebuah jaringan. Secara garis besar, algortima dijkstra membagi semua node menjadi dua, kemudian dimasukkan ke dalam tabel yang berbeda, yaitu table permanen dan tabel 
temporal. Pada tabel permanen adalah node awal yang sudah melalui proses pemeriksaan nilai-nilai positif atau negatif dan telah diubah dari tabel temporal menjadi permanen. Dan selanjutnya pada tabel temporal mempunyai nilai node yang sudah terhubung dengan node pada tabel permanen.

Langkah pertama untuk menentukan titik node yang menjadi node awal, lalu beri nilai bobot pada node pertama ke node terdekat satu per satu, algoritma djikstra akan memulai suatu pengembangan pencarian lintasan dari satu node ke node yang lain, dan ke node selanjutnya[4]. Logika pada Algoritma Dijkstra sebagai berikut:

1. Beri nilai bobot (jarak) awaluntuk setiap titik ke titik lainnya, lalu set nilai 0 pada node awal dan nilai tak hingga terhadap node lain yang belum memiliki bobot nilai.

2. Set semua node yang belum terjamah dan setnode awal sebagai node keberangkatan.

3. Dari node keberangkatan, pertimbangkan nodelain yang belum terjamah dan hitung jaraknya dari titik keberangkatan. Sebagai contoh, dengan nilai keberangkatan A ke B memiliki nilai bobot jarak 6 dan dari B ke node $\mathrm{C}$ berjarak 4, maka jarak ke $\mathrm{C}$ melewati $\mathrm{B}$ menjadi $6+4=10$. Jika jarak nilai suatu lintasan lebih kecil dari nilai sebelumnya, hapus data yang sudah tersimpan sebelumnya, dan simpan ulang nilai jarak dengan jarak yang baru.

4. Saat setelah menghitung nilai setiap jarak terhadap node lain, maka simpan data node yang telah terhitung sebelumnya sebagai nilai data node yang sudah terhitung sebelumnya. Data yang sudah terhitung tidak akan pernah di hitung kembali,karena nilai bobot node sebelumnya sudah terhitung. Maka jarak nilai yang sudah tersimpan adalah nilai jarak terakhir dan yang paling minimal nilai bobotnya.

5. Setnode belum terjamah dengan jarak terkecil (dari node keberangkatan) sebagai node keberangkatan selanjutnya dan lanjutkan dengan kembali ke step 3 .

Tahap awal yang dilakukan yaitu membandingkan setiap kemungkinan simpul yang dilalui, setiap titik mempunyai nilai yang tidak sama. Nilai suatu node yang sudah dilalui pada lintasan yang sebelumnya, tentu saja berbeda dengan node yang dilalui pada lintasan lainnya, sehingga dapat ditentukan rumus sebagai berikut[5]:

ToNodeDestination $=$ Node $1=>$ Node $2=>$ Node 3 $=>\ldots=>$ Noden

Setelah menentukan titik awal sampai ketitik tujuan, kita akan menjumlahkan setiap titik yang telah
getDistance $=$ Node $1+$ Node $2+$ Node $3+\ldots+$ Noden

Gambaran alur proses pencarian jalur terpendek pengiriman bahan bangunan seperti gambar berikut:

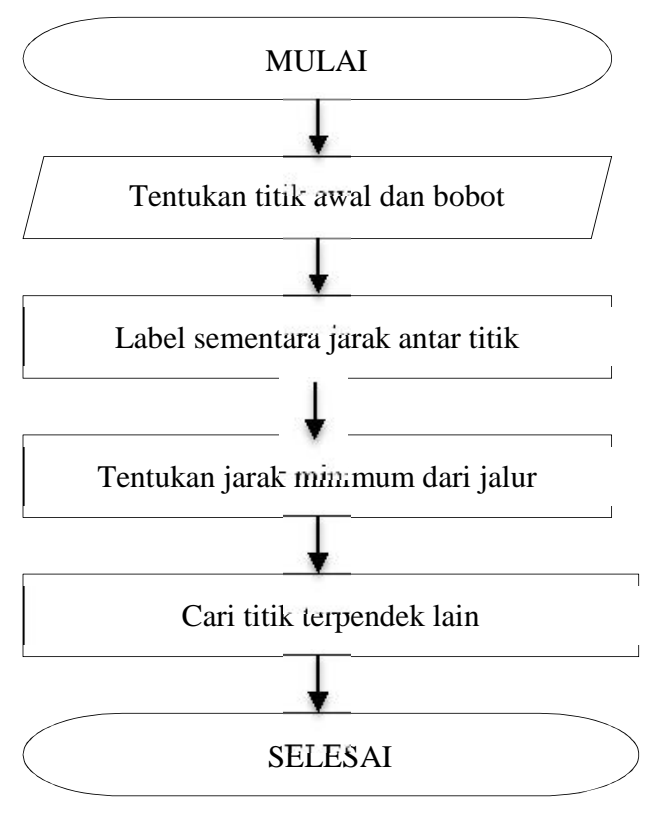

Gambar 1. Flowchart pencarian jalur terpendek

Setiap perpindahan titik memiliki jarak, hal pertama yang dilakukan adalah menghitung setiap simpul jarak pada setiap kemungkinan lintasan yang ada. Sebagai contoh pada kasus ini, terdapat 3 kemungkinan lintasan yang dapat dijangkaukendaraan:

Rute $1=$ Titik $0 \Rightarrow$ Titik $1 \Rightarrow$ Titik $2 \Rightarrow$ Titik $3 \Rightarrow$ Titik $4 \Rightarrow$ Titik $5 \Rightarrow$ Titik 6 .

Rute $2=$ Titik $0 \Rightarrow$ Titik $7 \Rightarrow$ Titik $10 \Rightarrow$ Titik $11 \Rightarrow$ Titik 6.

Rute $3=$ Titik $0 \Rightarrow$ Titik $7 \Rightarrow$ Titik $8 \Rightarrow$ Titik $9 \Rightarrow$ Titik $10=>$ Titik 11 = Titik 6 .

Menghitung jarak keseluruhan jarak masingmasing rute dalam satuan meter.

Rute $1=450+450+1100+4000+440+160=6560$ meter $(6.560 \mathrm{~km})$.

Rute $2=450+450+2700+3300+140=6740$ meter $(6.740 \mathrm{~km})$.

Rute $3=200+600+1600+2600+3300+140=$ 8440 meter $(8.440 \mathrm{~km})$.

Pada simulasi ini kita dapat mengambil kesimpulan bahwarute terpendek jatuh pada rute pertama, karena memiliki jarakyang paling dekat 
untuk sampai ke titik tujuan.

\subsection{Supply Chain Management}

Supply Chain Management disebut juga Rantai Pasokan merupakan pengelolaan suatu kegiatan yang mengendalikan terhadap pengadaan bahan, produksi, persediaan dan pengiriman produk kepada konsumen yang melalui distribusi yang mencakup administasi harian, operasi, logistik dan pengolahan informasi mulai dari pelanggan hingga ke pemasok.

Supply Chain Managemen juga merupakan salah satu cabang manajemen yang melibatkan distributor, pabrik atau manufaktur, penyedia logistik dan tentunya yang paling penting adalah pelanggan. Proses Supply Chain Management melibatkan beberapa pihak seperti pelanggan itu sendiri yang menjadi mata rantai pertama yang memberikan pesanan, lalu terdapat pihak perencanaan yang akan mempersiapkan perencanaan produksi.

Pembelian merupakan pihak ketiga yang terlibat dalam rangkaian supply chain management, terdapat pihak persediaan untuk memeriksa kualitas dan ketepatan jumlah kemudian disimpan didalam gudang. Pihak terakhir yang terlibat adalah bagian transportasi yang akan mengatur keberangkatan barang dari gudang untuk di kirimkan kepada pelanggan.

\section{Metode Penelitian}

Tahapan penelitian dari aplikasi pencarian jalur terpendek dalam pengiriman bahan bangunan yaitu melakukan observasi masalah yang biasanya terjadi pada pengiriman bahan bangunan yaitu masalah wilayah dan muatan. Analisa kebutuhan dilakukan setelah mendapatkan masalah pengiriman sehingga didapatkan bahwa kebutuhan aplikasi yaitu pencarian rute dan visualisasi pada maps.

Pencarian teori penunjang dan metode untuk menyelesaikan masalah sehingga didapatkan metode tabu search. Masalah pengiriman barang tersebut diuraikan dan studi literatur untuk menganalisa kebutuhan dan mencari teori penunjang pengembangan aplikasi.

Hasil analisis yang dapat dilakukan dari pencarian jalur terpendek pengiriman bahan bangunan yakni dengan memanfaatkan teori graf dengan metode djikstra. Metode djikstra dapat melakukan perhitungan dari beberapa kemungkinan jalur yang dapat dilalui sehingga hasil dari metode tersebut dapat memberikan rekomendasi berupa jalur-jalur mana yang dapat dilalui dalam satu proses pengiriman bahan bangunan.

Data-data toko bangunan yang telah melakukan order atau pembelian bahan bangunan akan dilakukan mapping atau pemetaan lokasi toko untuk didapatkan jalur-jalur serta nilai yang berada dalam jalur tersebut.

Proses pertama yakin dengan menentukan titik awal yang diibaratkan gudang penjualan utama yang dijadikan sebagai node awal. Perlu diberikan bobot pada masing-masing jarak dari satu node ke node lainnya. Dari node keberangkatan (gudang penjualan) akan dilakukan perjalanan ke titik atau node yang dilalui oleh node keberangkatan, setelah didapatkan nilai dari beberapa kemungkinan jalur yang dilalui maka akan diambil jalur yang memiliki bobot terkecil dan langkah-langah tersebut dilakukan terus menerus sampai dengan di node akhir atau titik terjauh dari toko tersebut.

\section{Hasil dan Pembahasan}

4.1 Daftar Toko

Toko bangunan yang telah melakukan pemesanan bahan bangunan akan direkap terlebih dahulu agar dapat dilakukan pemetaan titik sehingga mendapatkan gambaran peta garis perjalanan yang akan dilakukan.

\begin{tabular}{|l|l|}
\hline Id & Nama Toko \\
\hline A & Gudang Awal \\
\hline B & CV. Jalur Sutera \\
\hline C & Kahel Group \\
\hline D & Rasty Pratama \\
\hline E & CV. At-Taubah \\
\hline F & UD. Putra Sumber Alam \\
\hline G & UD. Sumber Waras \\
\hline H & UD. Rafi Jaya \\
\hline
\end{tabular}

Tabel 1. Contoh Data Toko Customer(Bahan Bangunan yang pesan bahan)

\subsection{Parameter Jenis Kendaraan Angkut}

Proses pengiriman barang tentunya tidak lepas dari adanya armada atau kendaraan yang digunakan untuk melakukan pengiriman bahan bangunan. Pada PT Putra Sejati Bahagia terdapat 3 armada yang biasa digunakan untuk pengiriman barang. Adapun pembagian armada kendaraan adalah sebagai berikut.

\begin{tabular}{|l|l|}
\hline Jenis Kendaraan & \multicolumn{1}{|c|}{$\begin{array}{c}\text { KapasitasPengiriman } \\
\text { (TON) }\end{array}$} \\
\hline Dump Truck & 1500 \\
\hline Truck & 1000 \\
\hline Pick Up & 500 \\
\hline
\end{tabular}

Tabel 2. Daftar jenis armada atau kendaraan

\subsection{Pemetaan Lokasi dan Pemberikan Bobot Jalur}

Setelah didapatkan daftar toko-toko yang telah melakukan pemesanan bahan bangunan, selanjutnya dilakukan pemetaan atau visualisasi lokasi yang akan 
membantu dalam proses selanjutnya. Pemberian bobot pada masing-masing jalur dilakukan supaya bisa mendapatkan jalur-jalur mana saja yang optimal dan lebih cepat.

Nilai bobot jalur didapatkan dengan menggunakan bantuan pengukuran jalur milik perusahaan google dalam aplikasi google maps. Gambar visualisasi titik lokasi toko seperti pada gambar berikut.

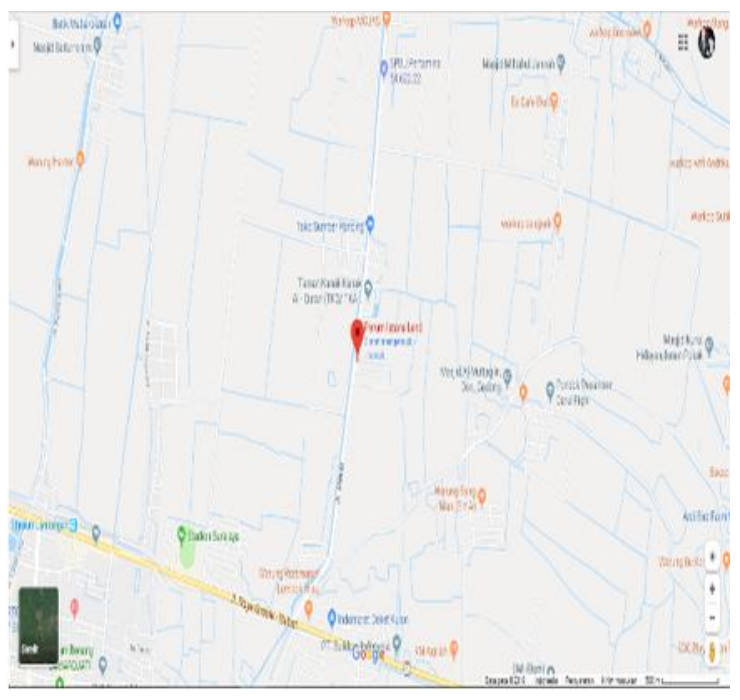

https://goo.gl/maps/UVxbAXz6Rf6ahvHz9 Gambar 2. Gambar Visualisasi Titik Lokasi Toko

\subsection{Data Jalan dan Akses Jalan}

Proses dalam pengiriman bahan bangunan ke toko melewati beberapa jalan poros kecamatan maupun jalan antar desa. Jalan yang akan dilalui perlu dilakukan mapping lapangan terlebih dahulu untuk menentukan jalan tersebut layak untuk dilewati atau tidak. Ada beberapa kategori penilaian jalan yang dapat dilalui seperti jenis jalan (bahan jalan), akses kendaraan yang diperbolehkan serta kelayakan jalan tersebut. Penjelasan jalan dan kategorinya seperti pada table berikut:

\begin{tabular}{|l|l|l|l|}
\hline Jalan & Jenis & \multicolumn{1}{|c|}{ Akses } & \multicolumn{1}{|c|}{$\begin{array}{c}\text { Bobot } \\
\text { Nilai } \\
\text { Jalan }\end{array}$} \\
\hline I & Aspal & $\begin{array}{l}\text { Dump, Truk, } \\
\text { Pickup }\end{array}$ & $15 \mathrm{~km}$ \\
\hline II & Aspal & $\begin{array}{l}\text { Dump, Truk, } \\
\text { Pickup }\end{array}$ & $5 \mathrm{~km}$ \\
\hline III & Aspal & $\begin{array}{l}\text { Dump, Truk, } \\
\text { Pickup }\end{array}$ & $8 \mathrm{~km}$ \\
\hline IV & Beton & Pickup & $7 \mathrm{~km}$ \\
\hline V & Beton & Truk, Pickup & $3 \mathrm{~km}$ \\
\hline VI & Aspal & Dump, Truk, & $9 \mathrm{~km}$ \\
\hline
\end{tabular}

\begin{tabular}{|l|l|l|l|}
\hline & & Pickup & \\
\hline VII & Beton & Pickup & $3 \mathrm{~km}$ \\
\hline VIII & Beton & Pickup & $11 \mathrm{~km}$ \\
\hline IX & Beton & Truk, Pickup & $2 \mathrm{~km}$ \\
\hline X & Beton & Truk, Pickup & $9 \mathrm{~km}$ \\
\hline XI & Beton & Pickup & $12 \mathrm{~km}$ \\
\hline XII & Beton & Truk, Pickup & $7 \mathrm{~km}$ \\
\hline XIII & Beton & Pickup & $5 \mathrm{~km}$ \\
\hline XIV & Beton & Truk, Pickup & $6 \mathrm{~km}$ \\
\hline XV & Beton & Pickup & $6 \mathrm{~km}$ \\
\hline XVI & Beton & Truk, Pickup & $4 \mathrm{~km}$ \\
\hline \multicolumn{3}{|l|}{ Tabel3. Jalan berserta kategori }
\end{tabular}

\subsection{Proses Metode Djikstra}

Pada percobaan penelitian untuk menentukan rute tercepat dalam proses pengiriman barang bangunan terdapat order daru toko UD. Putra Sumber Alam berupa semen dengan total berat $700 \mathrm{Kg}$. Pada waktu yang bersamaan juga terdapat permintaan barang berupa pasir sungai untuk toko UD. Sumber waras dengan total berat hanya $400 \mathrm{Kg}$.

Pada proses permintaan oleh toko mendapatkan berat total 1,1 TON. Jumlah pesanan berupa semen dan pasir yang mendapatkan jumlah berat mencapai 1.1 TON akan dilakukann uji untuk menentukan jenis kendaraan yang akan digunakan dalam proses pengiriman. Maka ditentukan bahwa pengiriman menggunakan satu armada yakni Dump Truck untuk mencapai efisiensi dan memangkas biaya pengiriman. Setelah didapatkan armada untuk pengiriman, langkah selanjutnya yakni menentukan jarak terdekat menuju toko UD. Putra Sumber Alam.

\begin{tabular}{|l|l|l|}
\hline \multicolumn{1}{|c|}{ Nama Toko } & \multicolumn{1}{|c|}{ Barang } & $\begin{array}{c}\text { Jumlah } \\
(\mathrm{Kg})\end{array}$ \\
\hline $\begin{array}{l}\text { UD. Putra Sumber } \\
\text { Alam }\end{array}$ & Semen & 700 \\
\hline $\begin{array}{l}\text { UD. Sumber } \\
\text { waras }\end{array}$ & Pasir & 400 \\
\hline CV. Jalur Sutera & Batu Bata & 500 \\
\hline Kahel Group & Pasir & 1000 \\
\hline Rasti Pratama & Besi & 300 \\
\hline CV. At-Taubah & Semen & 500 \\
\hline UD. Rsfi Jaya & Batu bata & 600 \\
\hline
\end{tabular}

Table 4. Jumlah permintaan toko

Penggunaan metode djikstra akan melakukan perhitungan secara looping dari awal keberangkatan sampai dengan lokasi terakhir[9]. Setiap perulangan akan dilakukan perhitungan pada masing-masing bobot. Percobaan perhitungan ini akan melakukan perjalanan dari titik A yakni Gudang Awal dan akan berhenti di tujuan akhir titik F yakni UD. Putra Sumber Alam. Pengiriman menggunakan kendaraan jenis truck.

Selama proses pencarian rute akan memperhatikan panjang jalan serta parameter lainnya 
seperti jenis jalan, akses jalan serta kelayakan jalan[8]. Pada iterasi pertama dari titik A sebagai node awal memiliki jalur yang dapat melalui titik B, C dan G. Dalam menuju titik B melewati jalan III yang memiliki nilai 8 , jika menuju titik $\mathrm{C}$ akan melewati jalan II yang memiliki nilai 5, sedangkan untuk menuju titik $\mathrm{G}$ akan melewati jalan I dengan nilai 15 . Sesuai dengan konsep metode djikstra yang memiliki bobot terkecil itu yang dipilih serta jalan yang dilewati layak serta akses jalan bisa dilalui truck maka dari titik A akan menuju titik $\mathrm{C}$ dan menjadikan titik C menjadi node selanjutnya. Detail proses perhitungan metode djikstra sesuai dengan tabel berikut:

\begin{tabular}{|c|c|c|c|c|c|}
\hline \multirow{15}{*}{$\begin{array}{l}A \\
-F\end{array}$} & $\begin{array}{c}\text { Iteratio } \\
\mathrm{n}\end{array}$ & $\begin{array}{c}\text { Visite } \\
\mathrm{d}\end{array}$ & $\begin{array}{c}\text { Curren } \\
\mathrm{t}\end{array}$ & $\begin{array}{c}\text { Nod } \\
\mathrm{e}\end{array}$ & $\begin{array}{c}\text { Valu } \\
\mathrm{e}\end{array}$ \\
\hline & \multirow{3}{*}{1} & \multirow{3}{*}{ A } & A & B & 8 \\
\hline & & & $\mathrm{A}$ & $\mathrm{C}$ & 5 \\
\hline & & & A & $\mathrm{G}$ & 15 \\
\hline & \multirow{3}{*}{2} & \multirow{3}{*}{$\mathrm{A}, \mathrm{C}$} & $\mathrm{C}$ & $\mathrm{B}$ & 12 \\
\hline & & & $\mathrm{C}$ & $\mathrm{D}$ & 14 \\
\hline & & & $\mathrm{C}$ & $\mathrm{G}$ & 8 \\
\hline & \multirow{3}{*}{3} & \multirow{3}{*}{$\begin{array}{c}\mathrm{A}, \mathrm{C} \\
\mathrm{G}\end{array}$} & $\mathrm{G}$ & D & 10 \\
\hline & & & $\mathrm{G}$ & $\mathrm{F}$ & 15 \\
\hline & & & $\mathrm{G}$ & $\mathrm{H}$ & 11 \\
\hline & \multirow{2}{*}{4} & \multirow{2}{*}{$\begin{array}{l}\text { A, C, } \\
\text { G, D }\end{array}$} & D & $\mathrm{B}$ & 13 \\
\hline & & & $\mathrm{D}$ & $\mathrm{E}$ & 19 \\
\hline & 5 & $\begin{array}{l}\mathrm{A}, \mathrm{C}, \\
\mathrm{G}, \mathrm{B}\end{array}$ & B & E & 24 \\
\hline & 6 & $\begin{array}{l}\mathrm{A}, \mathrm{C}, \\
\mathrm{G}, \mathrm{D}, \\
\mathrm{B}, \mathrm{E}\end{array}$ & $\mathrm{E}$ & $\mathrm{F}$ & 27 \\
\hline & 7 & $\begin{array}{c}\mathrm{A}, \mathrm{C}, \\
\mathrm{G}, \mathrm{D}, \\
\mathrm{E}\end{array}$ & $\mathrm{E}$ & $\mathrm{F}$ & 23 \\
\hline
\end{tabular}

Table 5. Detail perhitungan metode djikstra

\subsection{Hasil}

Setelah dilakukan percobaan perhitungan maka dapat di ambil hasil pengiriman untuk toko UD. Putra Sumber Alam yakni pesanan berupa semen dengan berat total $700 \mathrm{Kg}$ dan UD. Sumber Waras berupa pasir sungai dengan berat $400 \mathrm{Kg}$ dapat dilakukan pada waktu yang sama dengan menggunakan Dump Truck. Proses perhitungan metode djikstra akan terus diulang sampai dengan ditemukannya titik terakhir dari sekumpulan titik yang ada. Setelah dilakukan perhitungan maka dilakukan evaluasi awal untuk menentukan bahwa tidak ada kemungkinan jalur yang masih belum dilewati. Dalam Percobaan ini dari titik A menuju Titik F melalui jalan sebagai berikut :

$$
\mathrm{II}=>\mathrm{V} \Rightarrow \mathrm{IX} \Rightarrow \mathrm{X} \Rightarrow \mathrm{XVI}
$$

Serta selama perjalanan dari titik A ke titik F juga melewati beberapa toko yang dapat dilakukan pengiriman secara bersamaan.

$$
A=>C \Rightarrow G \Rightarrow D \Rightarrow E \Rightarrow F
$$

Toko yang dapat dilakukan pengiriman sekaligus ketika pengiriman dari Gudang ke toko UD. Sumber Putra Alam yakni.

1. Gudang Awal

2. Kahel Group

3. UD. Sumber Waras

4. Rasty Pratama

5. CV. At-Taubah

6. UD. Putra Sumber Alam

Dalam perjalanan dari gudang menuju pengiriman terakhir mendapatkan jarak berjumlah $23 \mathrm{KM}$. Gambaran jalur yang dapat dilalui seperti pada gambar berikut.

\begin{tabular}{|l|l|}
\hline Jarak & 23 KM \\
\hline Kendaraan Angkut & Dump Truk \\
\hline Rute Jalan & $\begin{array}{l}\text { II }=>\text { V } \\
\text { XVI }\end{array}$ \\
\hline
\end{tabular}

Table 5. Hasil perhitungan

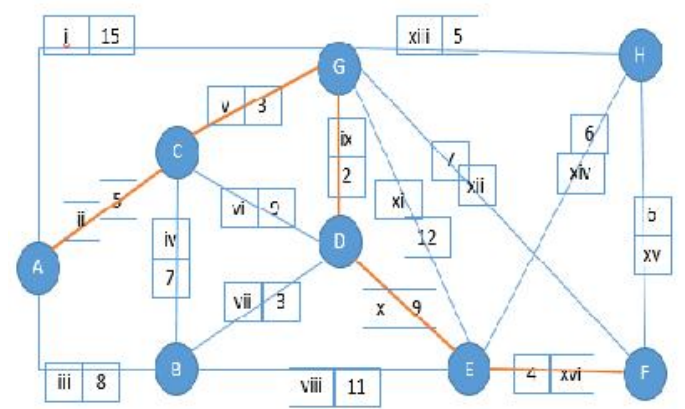

Gambar 3. Hasil jalur tercepat toko bangunan

\section{Kesimpulan}

Proses pencarian jalur tercepat pengiriman bahan bangunan secara bersamaan dapat dilakukan dengan menetukan titik lokasi toko-toko tujuan pengiriman bahan bangunan oleh PT. Putra Sejati Bahagia. Permasalahan tersebut dapat diselesaikan dengan menggunakan metode djikstra yang berbasis titik dan node, sehingga dapat membantu perusahaan dalam menentukan toko yang bisa dikirim bahan bangunan. Mendapatkan jalur-jalur yang dapat dilewati akan memberikan keuntungan lebih serta dapat memotong waktu dan biaya pengiriman karena proses pengiriman yang optimal tepat waktu dan tidak boros ketika dalam perjalanan pengiriman bahan bangunan. 
Dalam penelitian ini masih terdapat banyak kekurangan seperti belum dimasukannya parameter cost atau biaya yang dikeluarkan, dan jenis bahan bangunan permintaan toko, sehingga diharapkan kedepannya penelitian ini masih bisa dikembangkan lebih baik lagi.

\section{Daftar Pustaka}

[1] Basuki, A. "Algoritma Genetika Suatu Alternatif Penyelesaian Permasalahan Searching, Optimasi dan Machine Learning" http://lecturer.eepisits.edu/ basuki/lecture/ AlgoritmaGenetika.pdf (21 Januari 2019).

[2] Desiani, A. \& M. Arhani. Konsep Kecerdasan Buatan. Yogyakarta: Andi Offset, 2006.

[3] Kusumadewi, S. Artificial Inteligence (Teknik dan Aplikasinya). Yogyakarta: Graha Ilmu, 2003

[4] Munir, R. Matematika Diskrit. Bandung: CV Informatika, 2005.

[5] Ramadhani, Cipta.Teori dan Algortima Graph dengan Bahasa Java. Yogyakarta: Penerbit Andi, 2009

[6] Riyanto, Sistem Informasi Geografis Berbasis Mobile. Bandung.Informatika. 2019

[7] Sutarno, H. Matematika Diskrit. Malang: UM PRESS, 2003.

[8] Tanoe, Andre. GPS bagi pemula, dasar dasar Pemakaian Sehari hari. 2019

[9] Dwi Ardana, Ragil, Penerapan algoritma djikstra pada aplikasi pencarian rute bus trans semarang. SNIK 2016

[10] E. Erdiwansyah, M. Munawir, and R. Islamadina, "Analisis Hibridisasi Pencarian Lokal Dengan Populasi Dalam Travelling Salesman Problem (TSP)," J. Serambi Eng., vol. 2, no. 4, 2017.

[11] C. lilis Setiawati, T. A. Gani, and Y. Away, "Studi Pengaruh Hibridisasi Seleksi Roullete Wheel Dengan Tournament Selection Menggunakan Algoritma Berevolusi Pada TSP," J. Nas. Komputasi dan Teknol. Inf., vol. 2, no. 1, pp. 26-30, 2019. 